\title{
Larval development of Phylladiorhynchus pusillus (Henderson, 1885) (Decapoda, Anomura, Galatheidae)
}

\author{
Armando Mujica ${ }^{1}$, Francisca González-Cornejo ${ }^{1}$, Erika Meerhoff ${ }^{2,3,4}$ \& Beatriz Yannicelli ${ }^{2,3,4}$ \\ ${ }^{1}$ Departamento de Acuicultura, Universidad Católica del Norte, Coquimbo, Chile \\ ${ }^{2}$ Centro de Estudios Avanzados en Zonas Áridas (CEAZA), Coquimbo, Chile \\ ${ }^{3}$ Núcleo Milenio de Ecología and Manejo Sustentable de Islas Oceánicas (ESMOI) \\ Departamento de Biología Marina, Universidad Católica del Norte \\ ${ }^{4}$ Centro Universitario Regional Este, Rocha, Universidad de la República, Uruguay \\ Corresponding autor: Armando Mujica (amujica@ucn.cl)
}

\begin{abstract}
The larval development of Phylladiorhynchus pusillus is described from plankton specimens from the coast of Easter Island $\left(27^{\circ} 20^{\prime} \mathrm{S}, 109^{\circ} 40^{\prime} \mathrm{W}\right)$. The morphological description of five zoeae and megalopae are given, comparing the meristic characters of the larvae with those of other galatheids, and the differences that allow their discrimination. The first larval stage of $P$. pusillus differs from the larvae described for the genus Galathea, by the slight segmentation between the basi and exopodite of the third maxilliped, in addition to the presence of four plumose setae at the distal end of the exopodite. The second zoea can also be differentiated because the number of plumose setae is maintained at the distal end of the exopodite, with two setae less than its congeners of the genus Galathea. The scientific name of the species is discussed, which is one of the two Galatheidae species from the coasts of Chile, according to Ahyong et al. (2010) classification. The most notable difference of the examined zoeae, concerning the other species, and what is described for $P$. integrirostris, is the slight segmentation between the exopodite and the basipodite of the third maxilliped and the presence of four plumose setae on the distal end of the exopodite.
\end{abstract}

Keywords: Phylladiorhynchus pusillus; larvae; Decapoda; Galatheidae; Easter Island

\section{INTRODUCTION}

According to Retamal (2000), the family Galatheidae is composed of seven genera and approximately 258 species. Retamal \& Moyano (2010), pointed out that there are 23 species in Chile belonging to this family (six of the genus Munida, thirteen of the genus Munidopsis, one of the genus Cervimunida, one of the genus Pleurocondes, and two of the genus Phylladiorhynchus). In this regard, it should be noted that Ahyong et al. (2010) carried out a reclassification of the family Galatheidae, creating a new family (Munididae). The genera Munida, Cervimunida and Pleuroncondes, were assigned to the new family and Munidopsis to the family Munidopsidae. According to this new classification, Phylladiorhynchus integrirostris and $P$. pusillus are the only species of the family Galatheidae described for Chile. These two species are found in the waters around Easter Island, although $P$. pusillus would also be found from the Concepción Bay to Corral, in the Juan Fernández Archipelago and Salas y Gómez Islands (Poupin, 2003; Retamal, 2004; Retamal \& Moyano, 2010; Retamal \& Arana, 2016).

Baba et al. (2008), pointed out that P. pusillus has a worldwide distribution, highlighting its presence in Japan, Australia, New Zealand and China, as well as in the islands surrounding the French peninsula. The above is the product of the incorporation that Baba et al. (2008) did with three species of the genus Galathea (P. pusillus, G. pusilla and G. integra). These authors, to move Galathea lenzi under the synonymy of Phylladiorhynchus pusillus, analyzed the descriptions and photographs of Rathbun (1907), Balss (1924), Haig (1955) and Andrade (1985), who quoted G. lenzi in Juan Fernández Island and the coast of Valdivia (Chile). In Baba et al. (2008) work there is no reference

Corresponding editor: Luis Miguel Pardo 
to the work of Poupin (2003) and Retamal (2004), who finds specimens of G. lenzi in Salas y Gómez Island, describing and defining its distribution in Chile.

According to Retamal (2004), the adults of G. lenzi are characterized by having a pyramidal rostrum with serrated margins in the proximal region, a pair of spines in the cephalothorax middle region, and seven spines in the lateral margins, the first one is longer. The chelipeds have long and robust spines, especially on the mero and carpopodite; its abdomen is flexed from half its length. Besides, this author highlights that this galatheid is the smallest known, with ovigerous females of $4.0 \mathrm{~mm}$ in total length. There are no antecedents in the bibliography describing the development stages neither of this species nor of the others that were incorporated into the new classification of P. pusillus (Galathea lenzi, G. pusilla and $G$. integra). According to the previous information and considering the scarce data on the Chilean oceanic islands' carcinofauna, the present study is a contribution to the knowledge of P. pusillus larval stages from the area surrounding Easter Island.

The carapace of $P$. pusillus zoeae is globular and relatively triangular, with a broad rostrum at its base and pointed distally, prominent and oval eyes, notorious posterior middle notch and posterolateral spines sharp and serrated, abdomen with five somites, telson with a middle notch, and prominent spine on both sides, similar to the morphology of the zoeae of the family Galatheidae.

\section{MATERIALS AND METHODS}

In October 2014, April and September 2015, oceanographic cruises were carried out around Easter Island (Rapa Nui) $\left(27^{\circ} 20^{\prime} \mathrm{S}, 109^{\circ} 40^{\prime} \mathrm{W}\right)$, which included zooplankton surveys as part of the Núcleo Milenio ESMOI, NC120030 and CIMAR 21 Project. The zooplankton samples analyzed were collected in 13 oceanographic stations, using bongo nets $(60 \mathrm{~cm}$ of mouth diameter and $300 \mu \mathrm{m}$ of mesh opening), and the Tucker net system $\left(0.25 \mathrm{~m}^{2}\right.$ mouth area and $300 \mu \mathrm{m}$ of mesh aperture). The samples were collected between the surface to a maximum depth of $300 \mathrm{~m}$ and preserved in an alcohol solution (96\%). The galatheid larvae were separated and identified, using dichotomous keys (Báez, 1997; Medellín-Mora et al., 2009), and Fujita (2007) larvae descriptions of the genera.

The total length (TL) was measured from the tip of the rostrum to the posterior edge of the telson (excluding the processes), and the length of the carapace (CL) from the tip of the rostrum to the midpoint of the posterior edge of the carapace. The corporal somites are described in the anteroposterior order, the appendices and their setae from proximal to the distal end and from internal to external. The telson processes are described from external to internal, with the Roman numerals for the immobile thorns (I), lowercase letters for small setae (ii) and the Arabic numbers for the median setae (2-7).

The reduced number of megalopae caught, their small size and deterioration prevented the description of the antenna, maxillule and the first and third maxillipeds.

\section{RESULTS}

The general morphology of Phylladiorhynchus pusillus zoeae corresponds with that of the family Galatheidae. Globular carapace relatively triangular, with a broad rostrum at its base and pointed distally, prominent and oval eyes, notorious posterior middle notch and posterolateral spines sharp and serrated, abdomen with five somites, telson with a middle notch and prominent spine on both sides. The megalopa morphology is similar to the adult, but smaller in size, and body covered with a higher number of setae.

\section{First zoea}

Size: TL 2.22-2.46 mm, CL 0.66-0.80 mm ( $=12)$.

Carapace. Globose, with a short and thick rostral spine at its base and small spines at the distal edges. Sessile, prominent and oval eyes. Posterior margin with a deep middle notch between prominent spines. Small setae in the posterior and posterolateral margin (Fig. 1).

Antennule. Long, thin and unsegmented; with two terminal aesthetascs of similar length and three simple setae shorter than the aesthetascs; subterminal margin with a long plumose mushroom (Fig. 2a). Antenna. Biramous, protopodite with a large denticulate spine of similar length to the endopodite; length of endopodite slightly less than half of the scaphocerite, with short and plumose terminal setae; scaphocerite coarse, with a long and sharp terminal process and nine plumose setae of similar size on the inner edge (Fig. 2b).

Maxillule. Coxal and basal endite with five plumedenticulate setae of similar size; endopodite unsegmented, with two simple setae and two terminal plumose and a subterminal plumose on the inner edge (Fig. 3a).

Maxilla. Bilobate coxal and basal endite, with 4, 3 and 3, 3 setae, respectively; endopodite unsegmented with seven setae; scaphognathite with four plumose setae (Fig. 3b).

First maxilliped. Basipodite longer than wide, with $2+2+2+2$ setae on the inner edge, endopodite with segments, the last one of smaller size, all with setae in 

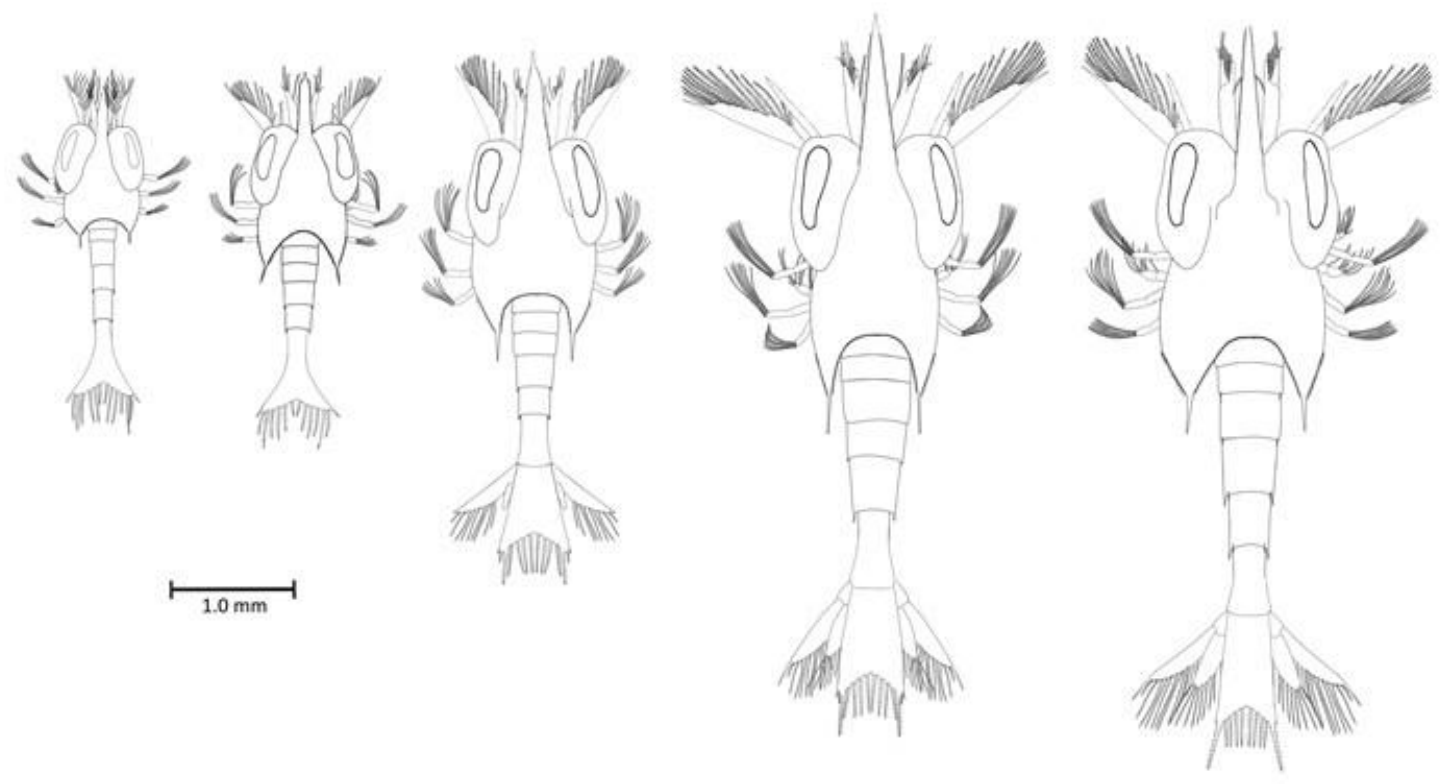

Figure 1. Phylladiorhynchus pusillus zoeae I-V, dorsal view.

a
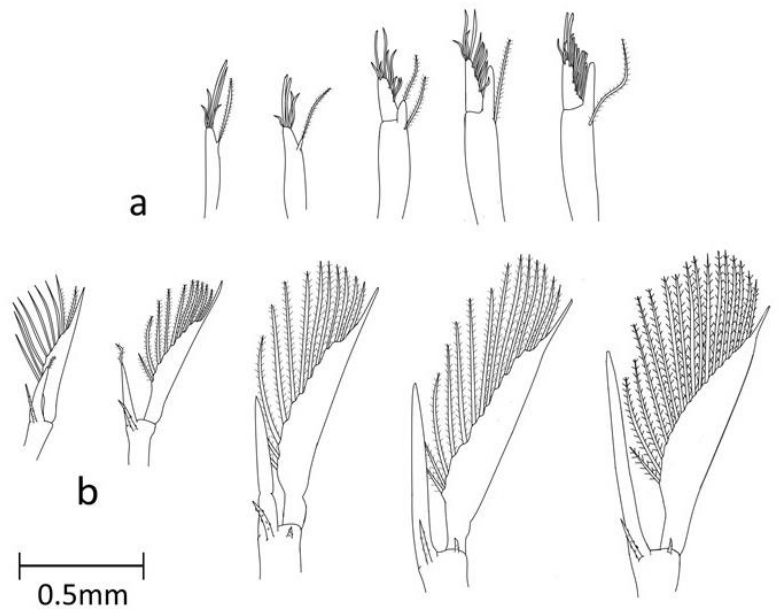

Figure 2. Zoeae I-V. a) Antennule, b) antenna.

the outer margin. Setae formula 2, 2, 1, 2, 4 (threeterminal and one short subterminal); exopodite with two segments of equal size; second segment with five long setae on its distal margin (Fig. 4a).

Second maxilliped. Basipodite rectangular, longer than wide, with two similarly sized internal setae; endopodite with four segments of similar size except the fourth (smaller) with 2, 2, 2, 4 (three terminal and one short terminal) setae; exopodite similar to the first maxilliped with two segments and four setae at the distal end (Fig. 4b).

Third maxilliped. Simple structure, segmentation developing with four plumose setae (Fig. 4c).
Abdomen. With five somites; third and fifth longer than wide, fourth and fifth with posterolateral spines; pleopods absent (Fig. 1).

Telson. Triangular in dorsal view, posterior edge with a central notch, with $7+7$ processes (telson formula I + 2-7) (Fig. 1).

\section{Second zoea}

Size. TL 2.82-3.02 mm, CL 0.96-1.14 mm ( $\mathrm{n}=10)$.

Carapace. Morphologically similar to the previous state, with a deeper notch in the posterior margin (Fig. $1)$.

Antenula. Without changes (Fig. 2a).

Antenna. Scaphocerite with one more seta more than in the previous state (10) (Fig. 2b).

Maxilula. Without changes (Fig. 3a).

Maxilla. Coxal and basal endite with 5, 1 and 4, 2 plumose setae; endopodite without change: scaphognathite with five plumose setae of similar size (Fig. 3b).

First maxilliped. Without changes (Fig. 4a).

Second maxilliped. Exopodite with more plumose setae at the distal end (5); the rest unchanged (Fig. 4b).

Third maxilliped. Segmentation between basi and exopodite; exopodite with a terminal plumose seta, more than in the previous state (5) (Fig. 4c).

Abdomen. Without changes (Fig 1).

Telson. Wider than in the previous state (Fig. 1). 
a
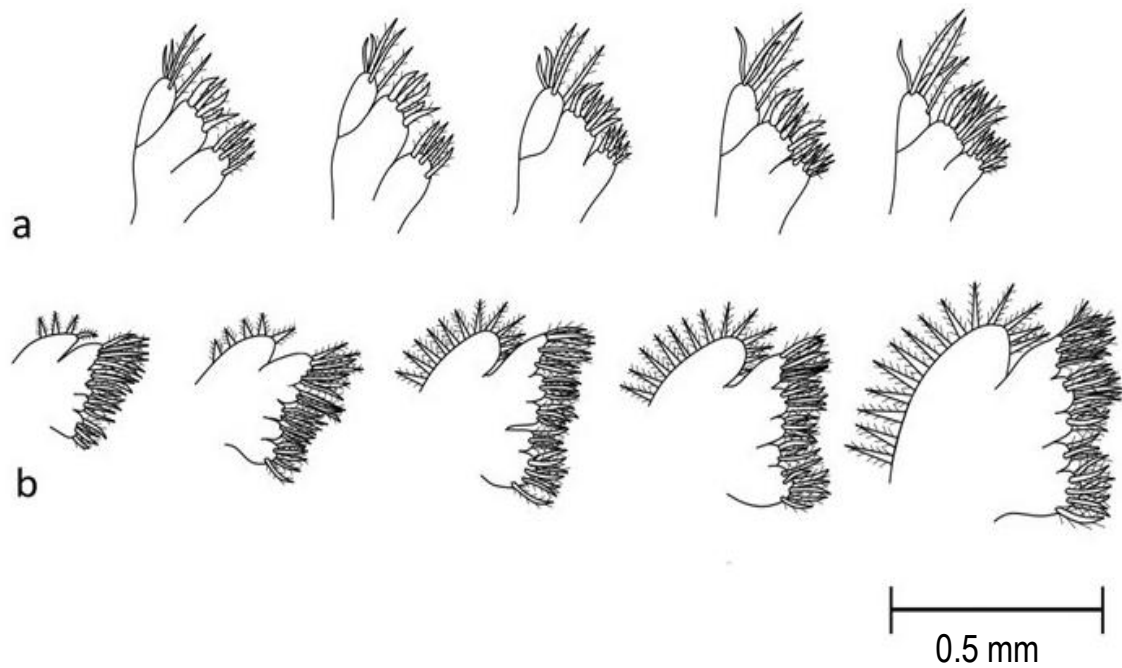

Figure 3. Zoeae I-V. a) Maxillule, b) maxilla.

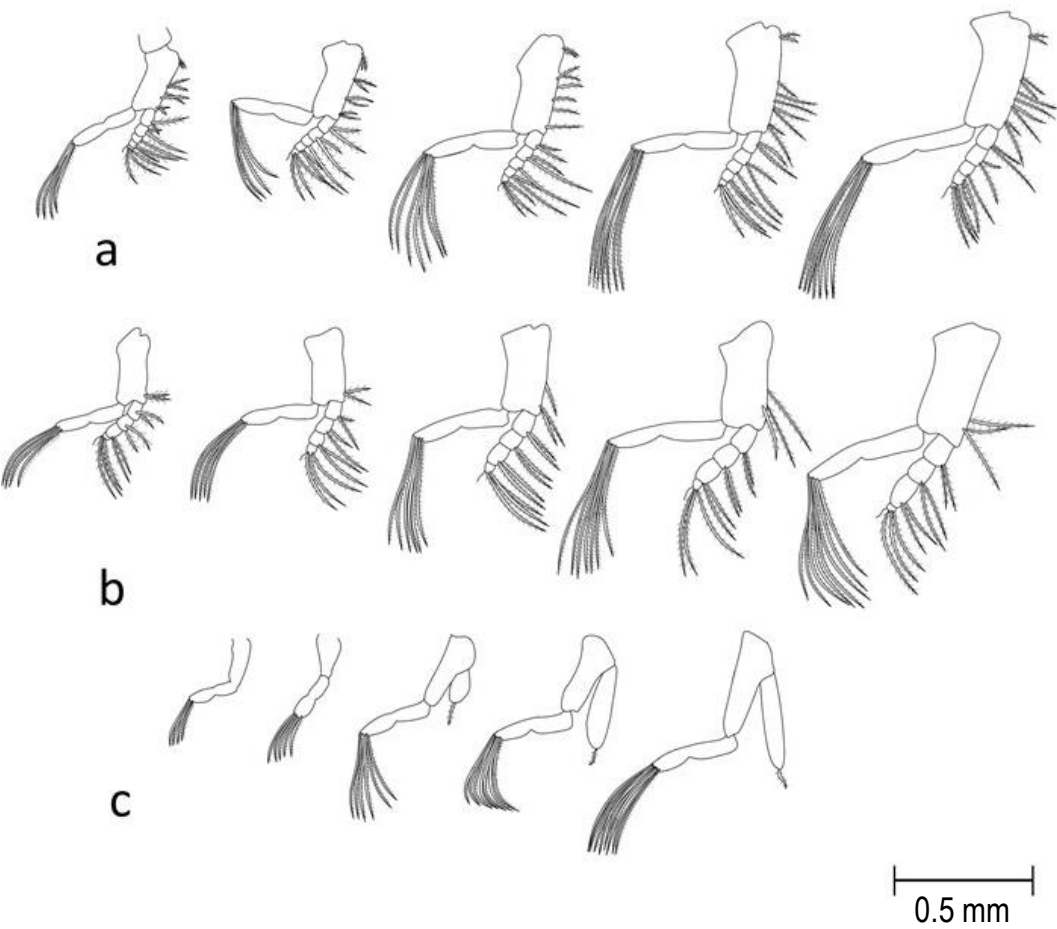

Figure 4. Zoeae I-V. Maxilliped a) I, b) II, and c) III.

\section{Third zoea}

Size. TL 4.06-4.48 mm, CL 1.33-1.68 mm $(\mathrm{n}=15)$.

Carapace. Stronger and longer rostral spine than in the previous state, posterior margin with a deeper notch and more prominent posterolateral spines (Fig. 1).

Antennule. Antennule with elongated protopodite provided with long plumose seta on the inner distal edge; endopodite with plumose setae of similar length than those to that of the protopodite; exopodite articulated with two aesthetascs and two terminal setae of lesser size; three rows of aesthetascs $(2,1,2)$ on the inner margin (Fig. 2a).

Antenna. Protopodite with two denticulate spines in the posterodorsal margin, the internal one of greater size; endopodite slightly longer than half of the scaphocerite, without terminal seta; scaphocerite with 12 plumose setae on the inner margin (Fig. 2b). 
Maxillule. Coxal and basal endite with seven apical plumedenticulate setae of similar size; endopodite unchanged (Fig. 3a).

Maxilla. Coxal and basal endite with seven, three and five plumose setae, respectively; endopodite with $2+2+3$; scaphognathite with 12 plumose setae of similar size (Fig. 3b).

First maxilliped. Basipodite with $2+2+1+1+1+1$ setae on the inner margin; endopodite with 2, 2, 1, 2, 4 setae (the fifth segment with three long setae and one small); exopodite second segment with seven plumose setae on the distal end (Fig. 4a).

Second maxilliped. Basipodite with three setae on the outer distal margin $(1+2)$, endopodite unchanged; exopodite with six plumose setae at the distal end of the second segment (Fig. 4b).

Third maxilliped. Basipodite longer than wide, without setae. Endopodite oval, with a small terminal seta; bisegmented exopodite, with six plumose setae of equal length at its distal end (Fig. 4c).

Abdomen. With six somites, fourth and fifth with posterolateral spines (Fig 1).

Telson. Telson trapezoidal, longer than wide; deeper central notch, with $7+7$ processes (formula: I+ii+III+47). Uropods biramous; endopodite naked developing; exopodite with nine plumose setae on the inner margin, the distal seta shorter than the others (Fig. 1).

\section{Fourth zoea}

Size. TL 5.18-5.39 mm, CL 1.82-2.03 mm $(\mathrm{n}=17)$.

Carapace. The rostral spine of similar length to the carapace, margins with finely serrated edges. The posterior notch more pronounced than in previous states (Fig. 1).

Antennule. Protopodite without changes; endopodite without setae, inner margin with four aesthetascs rows $(3,1,2,1)$, two aesthetascs and two terminal setae (Fig. 2a).

Antenna. Protopodite without changes; endopodite larger than in the previous stage, scaphocerite with 14 plumose setae (Fig. 2b).

Maxillule. Coxal endite and endopodite unchanged, basal endite with eight plumedenticulate setae (Fig. 3a).

Maxilla. Coxal and basal endite 3, 7 and 4, 6 setae respectively; endopodite with six setae; scaphognathite with 13 plumose setae of similar length (Fig. 3b).

First maxilliped. Basipodite inner margin with $2+1+$ 1+1+2+2 setae; endopodite with 2, 2, 1, 2, 3+I setae; exopodite unchanged (Fig. 4a).

Second maxilliped. Basipodite unchanged; endopodite with 2, 2, 2, 3+I setae; exopodite with eight terminal plumose setae (Fig. 4b).
Third maxilliped. Endopodite longer than the basipodite, with one apical seta; exopodite second segment with seven terminal plumose setae (Fig. 4c)

Abdomen. Unchanged (Fig 1).

Telson. Unchanged. Uropods with both branches developed, endopodite with three setae on the outer distal edge and four in the inner margin; exopodite with long terminal spine and ten plumose setae in the inner margin (Fig. 1).

\section{Fifth zoea}

Size. TL 6.02-6.44 mm, CL 1.96-2.24 mm ( $=13)$.

Carapace. Longer than in the previous stage, with longer posterior spines and notorious posterior internal and external margin setae (Fig. 1).

Antennule. Protopodite unchanged, with a plumose seta twice as long as the endopodite; exopodite with four aesthetascs rows $(3,3,3,2)$ on the inner margin. Distal end without change (Fig. 2a).

Antenna. Protopodite unchanged, endopodite of similar length as the scaphocerite; scaphocerite with 17 plumose setae (Fig. 2b).

Maxillule. Unchanged (Fig. 3a).

Maxilla. Coxal en basal endite with 8, 3 and 5, 7 setae respectively; endopodite with $3+2+5$ setae; scaphognathite with 14 plumose setae (Fig. 3b).

First maxilliped. Basipodite with $2+2+1+1+2+2$ setae; endopodite and exopodite unchanged (Fig. 4a).

Second maxilliped. Basipodite unchanged; endopodite with $2,2,2$, I+3 setae; exopodite with one more seta than the previous stage (8) (Fig. 4b).

Third maxilliped. Basi and endopodite unchanged; second segment with eight terminal setae (Fig. 4c).

Abdomen. Fourth and fifth somite with small posterolateral spines; from the second to the fifth with a fine seta on the subdistal posterior margin (Fig 1).

Telson. Rectangular, with $6+6$ processes (formula I+II+3-6); the four medium setae plumose and of equal size; process long, strong and plumedenticulate; endopodite uropods with four plumose setae of equal length on the distal end and four plumose setae on the inner margin; exopodite with a long and thick spine on the distal end and 12 plumose setae on the inner margin (Fig. 5).

\section{Megalopa}

Size. CL $2.16 \mathrm{~mm}(\mathrm{n}=2)$.

Carapace. Longer than wide, covered with numerous small setae. Wide based rostrum, with a sharp distal end and a spine on the distal third of each side. 

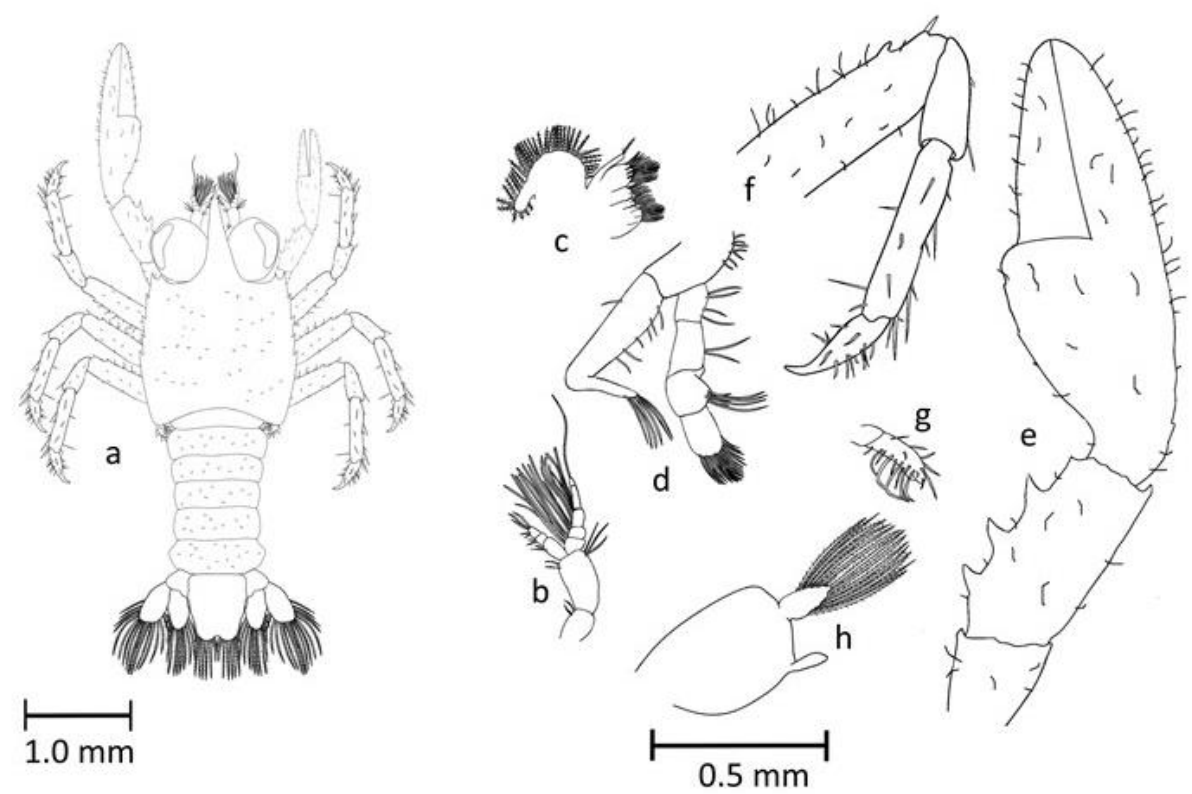

Figure 5. Megalopa. a) Dorsal view, b) antennule, c) maxilla, d) $2^{\text {nd }}$ maxilliped, e) $1^{\text {st }}$ right pereiopod, f) $2^{\text {nd }}-4^{\text {th }}$ pereiopod, g) $5^{\text {th }}$ pereiopod, h) pleopod.

Cephalothorax lateral borders serrated, with five spines. Anterodorsal edge of the orbital socket with a small spine. Prominent and slightly oval eyes (Fig. 5a).

Antennule. Birramose; bi-segmented peduncle with two setae on the distal border. The distal segment with two small setae on the distal internal border and three on the distal external margin. Endopodite threesegmented, the proximal first of similar length to the sum of the two distal, each with two setae on the inner margin, the third segment with three similar size terminal setae and longer than the segment. Exopodite with five segments, the first two wider than long, the third and fourth longer and narrower, the four proximal segments with aesthetascs, the fifth segment with a long terminal seta as long as the exopodite total length (Fig. $5 b)$.

Antenna. The specimens were found without antennas. Maxilla. Coxal and basal endite with distal setae and spines: endopodite long, thin, and with a terminal seta, scaphognathite with 37 plumose setae (Fig. 5c).

Second maxilliped. With seven simple setae of similar size in the proximal inner margin; endopodite with four segments, the three proximal segments with plumose setae on the outer edge $(4,2,7$, respectively), the fourth segment with setae in the distal end. Exopodite bisegmented, the first segment is notoriously long and robust than the distal one, with six setae on the inner margin and one external, the second segment with six terminal plumose setae (Fig. 5d).

First pereiopod. Asymmetric, tri-segmented, chelated and covered with small setae; mero, with a small distal spine on each side, carpus, with three robust spines on the inner edge, and a smaller one on the outer distal end (Fig. 5e).

Second to fourth pereiopod. Morphologically similar, long, with four segments covered with numerous setae. Mero with two spines on the distally outer edge; carpus shorter than half the mero's length; propodium twice the carpus length; dactylus distally sharpened and as long as the carpus (Fig. 5f).

Fifth pereiopod. Notoriously smaller, with two segments covered with numerous setae. Distal segment sub-chelated, with five setae on each side; the internal ones longer and distally curved (Fig. 5g).

Abdomen. With six somites wider than long, with small setae on dorsal surface; pleopods biramous, basipodites notoriously longer and wider; small endopodite without setae (Fig 5a). Exopodite lanceolate with 13 long plumose setae (Fig. 5h).

Tail fan. Telson, semi-rectangular with a bilobate distal edge and a small median notch with $8+8$ long and plumose setae, ones on the center of each lobe longer; uropods biramous, endo and exopodite with 13 and 17 plumose setae on the distal edge, central setae longer than marginal setae (Fig. 5a).

\section{DISCUSSION}

The zoea's general morphology described in the present study agrees with that of the family Galatheidae (Báez, 1997; Medellín-Mora et al., 2009). 
The Phylladiorhynchus pusillus first zoea described in this occasion, is very similar to that of $P$. integrirostris (Fujita, 2007), although smaller (LT), there being differences of 0.23 to $0.17 \mathrm{~mm}$ between the maximum and minimum sizes. The cephalothorax (LC) length is 0.40 to $0.29 \mathrm{~mm}$ less than that of $P$. integrirostris (Table 1).

Fujita (2007) describes only the first zoea of $P$ integrirostris, pointing out that it has morphological characteristics that allow it to differentiate from its congeners. Such as the lack of segmentation and number of setae on the maxillule endopodite $(1+4)$, number of setae on the maxilla's endopodite $(3+2+4)$, first maxilliped basi and endopodite sedation $(2+3+3+2,2,1,2,4$, respectively), presence of posterolateral spines on the fourth and fifth somite and lateral spines size of the telson. Of these characteristics, the last one is shared between $P$. integrirostris and $P$. pusillus (telson external spines of smaller size with respect to the rest of the setae, 7+7), but the second seta of $P$. pusillus is similar in size to the fourth to seventh setae, while in $P$. integrirostris the second seta is similar in size to the first one.

One of the differences between these two species' larvae is the size of the dorsal spine at the base of the antenna's endopodite. That of $P$. integrirostris is twice the size of the endopodite, while that of $P$. pusillus is slightly smaller than the endopodite length. Also, $P$. pusillus has nine setae on the exopodite and its congener 10 .

The number of setae on the basi and endopodite of $P$. pusillus first maxilliped is $2+2+2+2$ and $2,2,1,2,4$ respectively while $P$. integrirostris has two more setae in the basipodite and one more in the fifth segment of the endopodite (Fujita, 2007).

The first zoea maxillule of both species are similar, not segmented, and with the same number and disposition of their setae.

The most notable difference of the examined zoeae, relative to that described for $P$. integrirostris, is the slight segmentation between the exopodite and the basipodite of the third maxilliped and the presence of four plumose setae on the distal end of the exopodite, which is not found in zoea I as described by Fujita (2007).

The larval development of P. pusillus, composed of five zoeae and one megalopa, coincides with that described for $G$. rostrata, $G$. intermediate and $G$. inflata (Gore, 1979; Christiansen \& Anger, 1990; Fujita et al., 2001, respectively), contrary to that described for G. amboinensis (Fujita et al., 2003), the only galatheid that has been described with four zoeae and one megalopae.
The first larval stage of $P$. pusillus differs from the larvae described for the genus Galathea, by the slight segmentation between the basi and exopodite of the third maxilliped, in addition to the presence of four plumose setae at the distal end of the exopodite. The second zoea can also be differentiated because the number of plumose setae is maintained at the distal end of the exopodite, with two setae less than its congeners of the genus Galathea (Gore, 1979; Christiansen \& Anger, 1990; Fujita et al., 2001, 2003).

The presence of a plumose seta in the antennule basipodite is a characteristic shared with those of the Galathea genus, but the presence of two aesthetascs besides three simple setae on the exopodite, differentiate them from the zoeae of the four species of the genus Galathea, that have three aesthetascs and three simple setae (Gore, 1979; Christiansen \& Anger, 1990; Fujita et al., 2001, 2003). In addition, in all the zoea stages of $P$. pusillus, no small setae were observed in the antennule basipodite, a characteristic described from zoea II larvae of $G$. intermedia, $G$. rostrata, $G$. amboinensis and G. inflata (Gore, 1979; Christiansen \& Anger, 1990; Fujita et al., 2001, 2003).

The posterolateral spines of the fourth and fifth somite of the zoeae examined is a characteristic shared with those of G. inflata and G. amboinensis and the first two zoeae of G. rostrata (Gore, 1979; Fujita et al., 2001, 2003).

The absence of segmentation in the maxillule endopodite in all zoeae of $P$. pusillus is another characteristic that differentiates them from the larvae of the genus Galathea. Sedation on the endopodite of $P$. pusillus is equal to that of $G$. intermedia $(1+4)$, differing from $G$. rostrata by one lesser setae $(1+3)$ and from $G$. amboinensis and G. inflata by an additional seta in the lower segment (Gore, 1979; Christiansen \& Anger, 1990; Fujita et al., 2001, 2003).

The first two zoeae of $P$. pusillus have 9 to 10 plumose setae on the antenna's inner exopodite margin, differing in between one and two setae with the four species of the genus Galathea. In the fifth stage, $P$. pusillus has 17 plumose setae, while G. intermedia has 13, G. inflata 14-15 and G. rostrata 12-14 (Gore, 1979; Christiansen \& Anger, 1990; Fujita et al., 2001, 2003).

The first pair of $P$. pusillus megalopa pereiopods is asymmetric, the right being of smaller, unlike others of the Galathea genus mentioned above, which have these appendages symmetrical (Gore, 1979; Christiansen \& Anger, 1990; Fujita et al., 2001, 2003).

$P$. pusillus, like G. intermediate, have a pair of small spines on the outer anterodorsal border of the orbital socket, but they differ in the number of cephalothorax lateral spines (six in $G$. intermediate and five in $P$. 


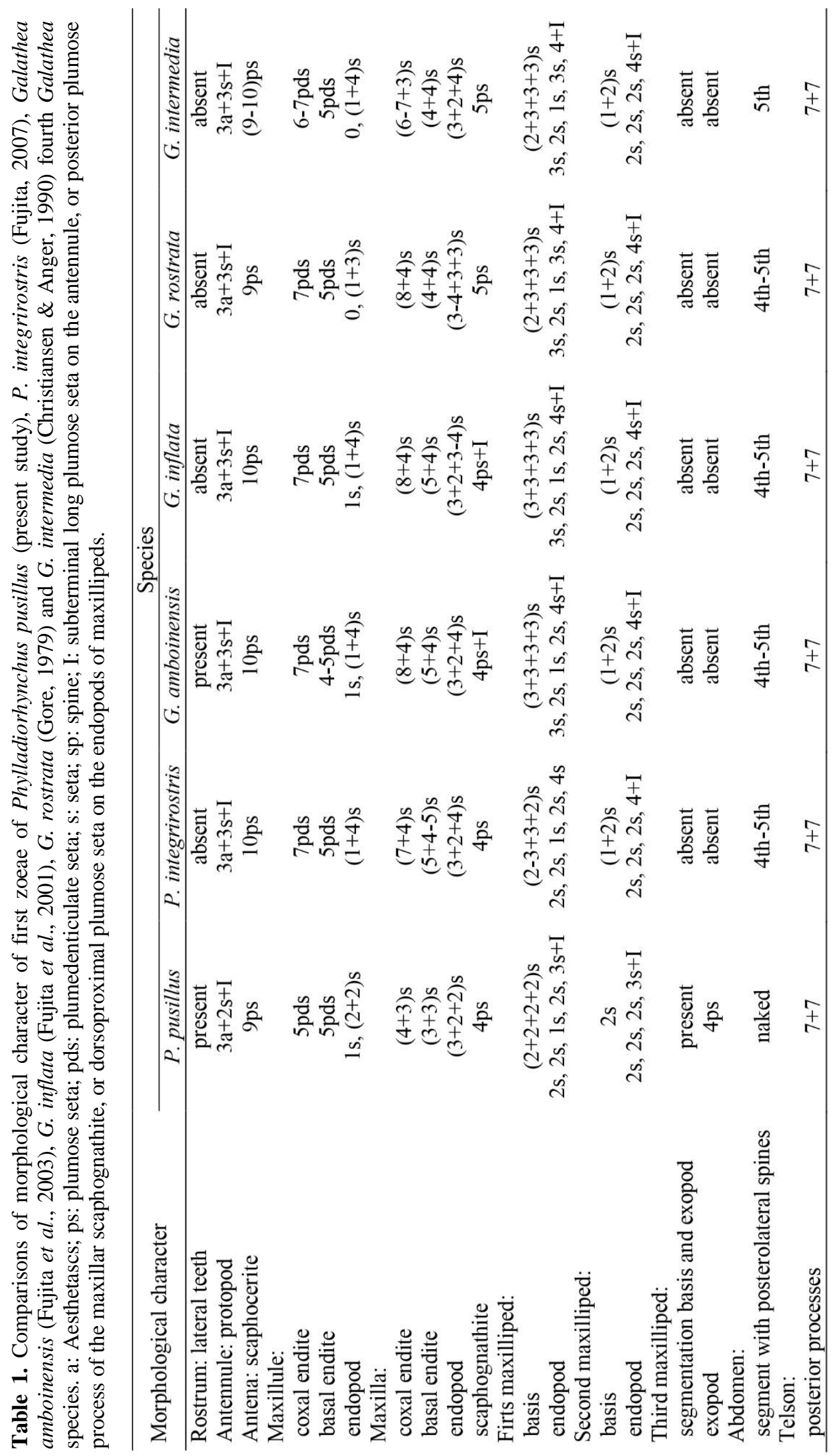


pusillus and G. rostrata). The latter, also shares the number of segments (3) in the antennule endopodite, although $G$. rostrata has one more seta (4) than $P$. pusillus on the distal end. In contrast to the above, $G$. intermedia, G. amboinensis and G. inflata have only two endopodite segments in this appendix, with 7-9, 34 and 4 setae on their distal end, respectively (Gore, 1979; Christiansen \& Anger, 1990; Fujita et al., 2001, 2003).

The number of setae on the megalopae scaphognathite of $P$. pusillus, $G$. intermedia, G. inflata, $G$. amboinensis and G. rostrata is similar, or their range is superimposed (37, 35 to 38,36 to 49,32 to 41,40 , respectively).

The megalopae pleopods morphology is one of the most discriminatory criteria between $P$. pusillus and the Galathea species. The P. pusillus pleopod basipodite is wider than long, notoriously differing from those of $G$. intermedia, G. rostrata, G. amboinensis and G. inflata, which are long and thin, with 7 to 8 setae in $G$. intermediate, $G$. rostrata and $G$. amboinensis exopodite, 11 in G. inflata and 13 in $P$. pusillus. The small endopodite in the objective species differs notoriously compared to the other megalopae, which are similar in length to the exopodite.

The presence of $P$. pusillus and $P$. integrirostris, being the only described species of the family Galatheidae from waters surrounding Easter Island (Retamal \& Moyano, 2010), the description of $P$. integrirostris zoea I (Fujita, 2007), and the morphological similarity of the megalopae examined with of $G$. lenzi adults, grants certainty to the identification of the described species larvae. Although the bibliographic antecedents analyzed, establish a reasonable doubt on its specific name (P. pusillus or G. lenzi).

\section{ACKNOWLEDGMENTS}

The authors thank the Millennium Nucleus of Ecology and Sustainable Management of the Oceanic Islands (ESMOI), the Postdoctoral Program FONDECYT/Chile 3150419 and the National Oceanographic Committee (CONA), executor of the marine scientific research cruise Cimar 21 Islas Oceánicas, that allowed the development of the present work.

\section{REFERENCES}

Ahyong, S., Baba, K., Macpherson, E. \& Poore, G. 2010. A new classification of the Galatheoidea (Crustacea: Decapoda: Anomura). Zootaxa, 2676: 57-68.

Andrade, H. 1985. Crustáceos decápodos marinos en el Archipiélago de Juan Fernández. In: Arana, P. (Ed.).
Investigaciones marinas en el Archipiélago de Juan Fernández. Escuela de Ciencias del Mar, Universidad Católica de Valparaíso, Valparaíso, pp. 109-116.

Baba, K., Macpherson, E., Poore, G., Ahyong, S., Bermúdez, A., Cabezas, P., Lin, C., Nizinski, M., Rodrigues, C. \& Schnabel, K. 2008. Catalog of squat lobsters of the world (Crustacea: Decapoda families Chirostylidae, Galatheidae, and Kiwaidae). Zootaxa, 1905: 1-220.

Báez, P. 1997. Key to the families of decapod crustacean larvae collected off northern Chile during an El Niño event. Investigaciones Marinas, 25: 167-176.

Balss, H. 1924. Decapoden von Juan Fernández. In: Skottsberg, C. (Ed.). The natural history of Juan Fernandez and Easter Island. Zoology, 3: 329-340.

Christiansen, M. \& Anger, K. 1990. Complete larval development of Galathea intermedia Lilljeborg reared in laboratory Culture (Anomura: Galatheidae). Journal of Crustacean Biology, 10(1): 87-111.

Fujita, Y. 2007. First zoea of two shallow-water galatheids, Lauriea gardineri (Laurie, 1926) and Phylladiorhynchus integrirostris (Dana, 1853) (Crustacea: Decapoda: Anomura: Galatheidae). Proceedings of the Biological Society of Washington, 120(1): 7485 .

Fujita, Y., Baba, K. \& Shokita, S. 2001. Larval development of Galathea inflata Potts, 1925 (Decapoda: Anomura: Galatheidae) described from laboratory-reared material. Crustacean Research, 30: 111-132.

Fujita, Y., Baba, K. \& Shokita, S. 2003. Larval development of Galathea amboinensis (Decapoda: Anomura: Galatheidae) under laboratory conditions. Crustacean Research, 32: 79-97.

Gore, R. 1979. Larval development of Galathea rostrata under laboratory conditions, with a discussion of larval development in the Galatheidae (Crustacea Anomura). Fishery Bulletin NOAA, 76: 781-806.

Haig, J. 1955. Reports of the Lund University Chile Expedition 1948-49. 20. The Crustacea Anomura of Chile. Lunds Universitets Arsskrif, 68 pp.

Medellín-Mora, J., Campos, N., Franco-Herrera, A. \& Jaimes, J. 2009. Taxonomía de larvas zoeas de crustáceos decápodos del área nororiental del mar Caribe colombiano. Boletín de Investigaciones Marinas y Costeras, 38(2): 55-73.

Poupin, J. 2003. Crustacea Decapoda and Stomatopoda of Easter Island and surrounding areas. A documented checklist with historical overview and biogeographic comments. Atoll Research Bulletin, 500: 1-50.

Rathbun, M.J. 1907. South American Crustacea. Revista Chilena de Historia Natural, 11: 45-50. 
Retamal, M.A. 2000. Decápodos de Chile. World Biodiversity Database CD-ROM Series. ETIUniversidad de Concepción. Springer-Verlag, Berlin.

Retamal, M.A. 2004. Decápodos de las islas oceánicas chilenas: Pascua y Salas y Gómez. Ciencia y Tecnología del Mar, 27(2): 55-75.

Received: 18 October 2018; Accepted: 11 June 2019
Retamal, M.A. \& Arana, P.M. 2016. Records of stomatopods and decapods, including descriptions of the species of commercial interest from the submarine rises and surrounding waters of the Chilean oceanic islands (southeast Pacific Ocean). Latin American Journal of Aquatic Research, 44(1): 16-33.

Retamal, M.A. \& Moyano, H.I. 2010. Zoogeografía de los crustáceos decápodos chilenos marinos y dulceacuícolas. Latin American Journal of Aquatic Research, 38(3): 302-328. 